\title{
Holder Norsk politiutdanning mål (slik politiet selv vurderer den)?*
}

Geir Aas, PhD, studieleder, Politihøgskolen i Oslo

Gunnar Thomassen, førsteamanuensis, Politihøgskolen i Oslo Annette Sund, cand.polit. seniorrådgiver, Politihøgskolen i Oslo

\begin{abstract}
The Norwegian Police University College is required to regularly evaluate and ensure the quality of the education in order to maintain its accreditation as an institution of higher education. A central aspect of this quality control is to make sure that the education is relevant for the field of practice and the policing profession. The Police University College has therefore on three occasions since 2006 sent out a survey to police officers three years after graduation and asked them to evaluate the relevance of the education in general, and more specifically to evaluate their own qualifications in different areas of competence. A similar questionnaire was sent to the supervisors of the post-graduates to get a broader comparative perspective.

The overarching aim of this article is to find out to what degree newly educated police officers and their leaders perceive the police education to provide a sufficient preparation for the police profession. To shed light on this question we will present and analyse data from the "quality surveys" mentioned above, but mainly from the 2015 survey. Overall, the findings presented in the article suggest that both the newly educated police officers and their leaders generally perceive the education to provide a sufficient preparation for the police profession. However, the leaders tend to give a better score than the newly educated police officers both overall and on specific qualification. Moreover, when looking into specific areas of competences we find that both groups tend to give the lowest scores on physical and operational qualifications such as use of firearms. A discussion of possible causes and implications of the findings is included in the article.
\end{abstract}

* Does the Norwegian police education achieve its self-defined goals? 


\section{Innledning}

Politihøgskolen har i tråd med NOKUT-krav kvalitetssikret sin utdanning gjennom de såkalte «kvalitetsundersøkelsene» ved fire anledninger (Hansen 2006, Bråten 2010, Aas 2014).

De to første undersøkelsene ble utført med spørreskjema til både nyutdannede og deres ledere. Spørreskjemaene inneholdt en rekke spørsmål relatert til deres syn på politiutdanningen som kunnskapsplattform for politiyrket. Den tredje studien frembrakte kvalitative data på disse spørsmålene, der formålet var å gå bak de kvantitative data i de foregående undersøkelsene og dokumentere refleksjoner om utdanningen på en dypere og mer helhetlig måte (Aas $2014 \mathrm{a}, \mathrm{b}$ ). I denne artikkelen vil vi presentere noen funn fra den fjerde og siste spørreundersøkelsen som ble samlet inn i 2015, her referert til som «Kvalitetsundersøkelsen 2015», ${ }^{1}$ men også med et blikk på tidligere undersøkelser. Gjennom disse fire studiene er det mulig å studere oppfatningene av politiutdanningen over tid.

Den bærende ideen bak disse undersøkelsene er at kvaliteten på politiutdanningen kan måles indirekte ved å spørre om hvor godt de nyutdannede fungerer $\mathrm{i}$ polititjenesten, sett både med de nyutdannedes og ledernes øyne. Det er selvsagt noen begrensninger knyttet til å benytte politiutøveres egne vurderinger av utdanning og kompetanse for yrkesutøvelse. Politiutøvere, både nyutdannede og ledere, vurderer disse spørsmålene gjennom sine egne kulturelle briller. Publikum, i alle sine variasjoner og grupperinger som møter politiet i ulike sammenhenger, ville kanskje ha andre og vel så interessante vurderinger av utdanning og politiutøvelse. Samtidig bør både nyutdannede og deres ledere ha en sentral stemme når politiutdanningens verdi og relevans skal vurderes. Det er denne stemmen som skal bringes til analyse i denne studien.

Kvalitetsundersøkelsen har til hensikt å undersøke både om nyutdannede i tilstrekkelig grad opplever at målene for utdanningen er oppnådd, og hvordan deres nærmeste ledere vurderer de samme forholdene. Ledere i politiet er stilt flere av de samme spørsmålene som kandidatene. På den måten avdekkes det om disse to gruppene har ulike vurderinger av kvaliteten på kandidatenes kompetanse som relativt nyutdannede.

Kandidatene i den siste undersøkelsen startet sin utdanning i 2009, og har gjennomført politiutdanningen etter omfattende endringer i tråd med rammepla-

1. Kvalitetsundersøkelsen 2015 er ikke publisert tidligere og foreligger bare som et internnotat lagt ut på Politihøgskolens interne nettsider (Sund, Aas, Nilsen, Thomassen og Hove, 2017). Denne artikkelen representerer et utvalg av data og en bearbeiding av hele studien. 
nendringene i 2007. Kort beskrevet handler denne reformen om overgangen fra fagsøyler til profesjonssøyler for å styrke det tverrfaglige fokuset i politiutdanningen (Politihøgskolen 2007). Gjennom rammeplanendringen ble utdanningens relevans for praksis forsøkt styrket ved å etablere en større integrasjon mellom de såkalte teoretiske og praktiske fag. ${ }^{2}$

I disse fire kvalitetsundersøkelsene har Politihøgskolen innhentet data først og fremst på spørsmål om i hvilken grad politiutdanningen tilfredsstiller samfunnets krav til politiet, utdanningens evne til å forberede kandidatene til politiyrket, samt forberedelser og kvalifikasjoner til en lang rekke oppgaver i politiyrket. En problemstilling som kan tjene som fellesnevner for disse spørsmålene, og som også blir denne artikkelens forskningsspørsmål, lyder slik;

I hvilken grad vurderer nyutdannede politibetjenter og deres ledere politiutdanningen som en tilstrekkelig forberedelse til politiyrket?

Denne problemstillingen retter seg først og fremst mot den siste kvalitetsundersøkelsen, som denne artikkelen tar utgangspunkt i, men også de foregående undersøkelsene når man til dels har stilt like spørsmål i disse undersøkelsene. Det ligger i artikkelens tittel om hvorvidt «politiutdanningen fortsatt holder mål» at det er kontinuitet mellom disse undersøkelsene. (Forskjellene mellom den siste og de tidligere kvalitetsundersøkelsene vil bli klargjort etter hvert).

\section{Teoretiske rammer for studien}

Kompetanse som mål for utdanningen

Et av de sentrale temaene i profesjonsforskningen er spørsmålet om hva som bidrar til at en utdanning kan sies å ha kvalitet. På den ene siden finner vi det som ligger i selve utdanningens vesen, en «formell kompetanse» som er dokumentert primært i form av eksamen og vitnemål. Den formelle kvalifikasjonen kan betegnes som en sosialt konstruert kvalifikasjon, ikke nødvendigvis som kompetanse (Nygren og Fauske 2010). På den annen side finner vi begrepet om «realkompetanse», som retter seg mot mestring av arbeidsoppgavene i en spesifikk yrkeskontekst (Mausethagen og Smeby 2017). I den grad vi kan si at en utdanning har kvalitet, må disse to kompetanseformene til en viss grad overlappe hverandre, og

2. Før 2007 ble politiutdanningen inndelt i fagsøylene politi-fag, juridiske fag og samfunnsvitenskapelige fag og språk. Rammeplanen av 2007 ordnet utdanningen i 5 hovedområder (profesjonssøyler) som Politi og samfunn, Metode, Operative oppgaver, Forebyggende oppgaver og Etterforskning. Alt faginnhold i utdanningen ble nå organisert under disse hovedområdene, også praksisåret B2. 
ha det som kalles «relevanskvalitet» (Stortingsmelding 16, 2016-2017). En kvalitetsundersøkelse er nettopp med på å undersøke hvorvidt denne overlappingen er til stede.

Rammeplanen og andre styringsdokumenter for politiutdanningen anvender begrepene «kunnskaper», «ferdigheter» og «generell kompetanse», hentet fra Nasjonalt kvalifikasjonsrammeverk ${ }^{3}$ (Politihøgskolen 2014). I en evaluering av rammeplanen av 2014 finner Ulskov Nielsen at kompetanse-begrepet blir noe usynlig i den norske politiutdanningen. Han finner mye om hva politistudentene skal vite noe om (kunnskaper), og hvilke ferdigheter de skal inneha etter endt studium, men lite om handlingskompetansen kandidatene bør besitte for å håndtere praktiske politioppgaver (Ulskov Nielsen 2016).

Hvis vi studerer kompetansebegrepet nærmere, og i tråd med Nygren og Fauske (2010), finner vi at kompetanse rommer en rekke dimensjoner - som relevant viten, ferdigheter, kontroll over ytre betingelser, identitet og handlingsberedskap. De forklarer videre;

«At have en bestemt professionel kompetence er at have relevant fagkundskab som gør personen i stand til at mestre en eller flere af de faglige opgaver, der er tillagt professionen i forhold til bestemte krav» (Nygren og Fauske 2010, s. 92).

Dette er imidlertid en individ-orientert definisjon av handlingskompetanse. Nygren og Fauske stiller i den forbindelse følgende treffende spørsmål; «Hvis vi vil lede efter en bestemt professionel handlekompetence, hvor skal vi så lede: Inde i individet eller i individets omverden?» (Nygren og Fauske 2010, s. 97). I deres tenkning kan kompetanse bare finnes i relasjonen mellom indre og ytre betingelser, mer presist mellom enkeltaktørers handlinger og en sosiokulturell og materiell handlingskontekst. Videre sondres det mellom individuell- og felles-kompetanse. Felles-kompetansen blir utviklet når flere arbeider sammen, og blir til mer enn summen av de individuelle kompetanser (Nygren og Fauske 2010, s. 47, 97). Denne undersøkelsen retter seg imidlertid hovedsakelig mot den individuelle kompetansen, og vi vil i det følgende anvende kompetansebegrepet som summen av kunnskaper og ferdigheter som de nyutdannede er i besittelse av.

3. https://www.nokut.no/siteassets/nkr/nasjonalt_kvalifikasjonsrammeverk_for_livslang_laring _nkr_nn.pdf 


\section{Utdanningskvalitet}

Når utgangspunktet for artikkelen er Politihøgskolens egne kvalitetsundersøkelser kreves det en nærmere avklaring av kvalitetsbegrepet. Hva er kvalitet i høyere utdanning, og hvordan kan den måles? Politiutdanningen har i tråd med kravene i Lov om universiteter og høyskoler $\S 1-6$, samt Studietilsynsforskriftens $\S 4-1$ interne kvalitetsmål som kategoriseres som inntaks, -ramme-, program- undervisning- samt resultat og relevanskvalitet (Politihøgskolen 2018).

I kvalitetsundersøkelsene forstås kvalitet som utdanningens evne til å overlappe med praksisfeltets krav og forventninger til hvilken kompetanse den nyutdannet skal kunne bidra med. Her pekes det dermed utover - mot praksisfeltet - og fokuserer på utdanningens relevans for selve yrkesutøvelsen. Undersøkelsene gir dermed kunnskap om og i hvilken grad utdanningen oppleves som relevant, både av kandidatene og av deres ledere. Det er overgangen fra studentrolle til politirolle som settes i sentrum for kvalitetsundersøkelsene, inkludert denne studien. Dermed har vi også beveget oss inn i profesjonsvitenskapen som forskningsfelt.

Kvalifisering for profesjonsutøvelse, særlig for profesjoner som lærere, sykepleiere, sosialarbeidere - og etter hvert også politiet, er en av de sentrale tema $\mathrm{i}$ profesjonsforskningen (Molander og Terum 2010). Politiet har som de andre nevnte utdanningene et treårig utdanningsforløp hvor praktiske ferdigheter og erfarings- og forskningsbasert kunnskap blir forsøkt integrert (Smeby og Mausethagen 2017, Hove 2012). Profesjoner kan nettopp karakteriseres som yrkesgrupper som anvender generell, abstrakt og teoribasert kunnskap på en skjønnsmessig måte i konkrete og reelle hendelser - eller «abstract knowledge to particular cases» for å si det med en klassiker i profesjonsvitenskapen (Abbott 1998, s. 8).

Det mest markerte utviklingstrekket ved utdanningene for disse profesjonene (også ofte benevnt som semiprofesjoner) er forflyttingen av opplæring i praksisfeltet til opplæring i en høgskolekontekst. «Akademisering» og «akademisk drift» har vært anvendt som nøkkelbegreper i denne sammenhengen (Heggen 2010, Messel og Smeby 2017). Disse begrepene signaliserer en avstand mellom opplæring og yrkesutøvelse. I politiutdanningens historie er denne kløften blitt stadig tydeligere med utviklingen fra konstabelkurs frem til 2. verdenskrig, dernest en toårig etatsutdanning helt frem til begynnelsen av 1990 årene - og til en høgskoleutdanning fra 1992 (Hove 2012). En mer utdannet, kritisk og kravstor befolkning, i et samfunn med økende grad av kompleksitet, lanseres gjerne som de strukturelle forklaringene på at det ikke lenger er tilstrekkelig med en politiutdanning som bare hviler på erfaringsbasert kunnskap. Kravet om at kunnskapsbasert politipraksis skal støtte seg til forskning har eskalert i politiutdanningens historie 
(Aas 2014, Hove 2012). Et spørsmål vi kommer tilbake til er hvor sentral forskningsbasert kunnskap er i vurderingen av politikandidatenes kompetanse.

\section{Data og metode}

Data til denne undersøkelsen er hentet fra Politihøgskolens kvalitetsundersøkelse fra 2015 som i likhet med undersøkelsene fra 2010 og 2006 er basert på surveydata. Spørreskjema ble sendt ut til to ulike respondentgrupper. Den ene respondentgruppen er de vi kaller kandidatene, dvs. politiansatte som var nyutdannet fra PHS i 2012, og som hadde vært inntil tre år i politiyrket på undersøkelsestidspunktet. Den andre respondentgruppen er kandidatenes nærmeste ledere i politiet. Svarprosenten for begge respondentgruppene er relativt høy og nokså lik tidligere undersøkelser (Hansen, 2006, Bråten, 2010). Av kandidatene var det 249 av 456 som svarte på undersøkelsen, dvs. ca. $55 \%$, mens det i ledergruppen var 231 av 352 som svarte på undersøkelsen, dvs. ca. $66 \%$. Videre synes respondentene i begge utvalgene å være representative for sine respektive populasjoner når det gjelder kjønnsfordeling. I kandidatutvalget er ca. $39 \%$ kvinner, hvilket er den samme andelen kvinner som ble tatt opp i kullet som gikk ut i 2012 (Politihøgskolen, 2013a). I lederutvalget er det ca. $17 \%$ kvinner, noe som er representativt i forhold til andelen kvinnelige ledere med politiutdanning i politiet (16\%) i 2015 (Politidirektoratet 2016).

Vi har dessverre ikke fått tilgang til andre demografiske data som kan si noe om representativitet, men har samtidig ingen indikasjon på at det er noe systematisk frafall av respondenter. Selv om svarprosenten må sies å være svært god tatt i betraktning at undersøkelser rettet mot politietaten som oftest har en svarrate under $50 \%$, så er det likevel et frafall på henholdsvis $45 \%$ (kandidater) og $34 \%$ (ledere) i denne undersøkelsen. Det kan være at disse skiller seg ut fra de som har svart når det gjelder oppfatninger om kvalifikasjoner, så vi må derfor ta høyde for at vi kunne fătt noe andre resultater hvis hele populasjonen hadde svart.

Vi har inkludert spørsmål om generelle kvalifikasjoner så vel som konkrete kvalifikasjoner i spørreskjemaene. På de fleste spørsmålene i spørreskjemaene, og alle spørsmålene som er inkludert i denne undersøkelsen, er det anvendt en skala som går fra 1 til 6 der respondentene angir og graderer sine svar. I resultatdelen vil vi derfor i hovedsak presentere og sammenlikne gjennomsnittsskårer for henholdsvis kandidater og ledere ved bruk av figurer. I den grad vi har tilgang på sammenliknbare tall fra 2006 og 2010 så vil de også bli presentert sammen med resultatene fra 2015. Der vi har signifikanstestet forskjeller over tid (med Independent t-test) har vi lagt til grunn 2006 som referanse ettersom dette er det ene- 
ste året utenom 2015 hvor vi har tilgang på relevante data for å gjøre en slik utregning.

Gjennom denne studien nås et representativt utvalg av relevante aktører som kan si noe om i hvilken grad de opplever at Politihøgskolen lykkes med å gi politiutøvere de rette kvalifikasjonene. Videre gir studien muligheter for å sammenlikne resultater over tid. Det er imidlertid en del åpenbare utfordringer knyttet til validitet ved bruk av spørreundersøkelser for å måle kvalitet. En åpenbar svakhet er at kandidatene og lederes oppfatninger ikke nødvendigvis sier noe om det rent faktisk er slik at utdanningen gir de rette kvalifikasjonene. Respondentene gir en subjektiv vurdering og ikke et objektivt mål på kvalifikasjoner. Videre er det også slik at selv om spørreskjema gir et godt bilde på kvalifikasjoner, så er det ikke gitt at det utelukkende er et resultat av utdanningen. Man kan tenke seg god yrkesutøvelse til tross for utdanning og vice versa. I tillegg er det også slik at ved bruk av standardiserte spørreskjema risikerer man å gå glipp av relevant informasjon ved at man ikke får stilt alle relevante spørsmål og dermed fanget inn all relevant informasjon. Vi mener likevel at de foreliggende data bør kunne gi en viss indikasjon på om Politihøgskolen gir en adekvat utdanning, nettopp fordi de fremste brukerne av utdanningen, de nyutdannede og deres ledere, erfarer hvordan kompetanse ervervet fra utdanningen blir utøvd i en yrkeskontekst. Sammenholdt med tidligere undersøkelser, både kvantitative og kvalitative, burde vi ha et utgangspunkt for å si noe kvalifisert om dagens politiutdanning.

\section{Resultater}

\section{Samfunnets krav til politiet}

Et overordnet spørsmål som har blitt stilt i alle de tre kvalitetsundersøkelsene, og til begge respondentgruppene, er i hvilken grad man mener politiutdanningen tilfredsstiller samfunnets krav til politiet. Respondentene er bedt om å ta stilling til spørsmålet på en skala fra 1 til 6 (hvor 1 indikerer i svært liten grad og tallverdien 6 i svært stor grad). I figur 1 er gjennomsnittsverdiene for begge gruppene og for alle tre måletidspunktene oppgitt slik: 
Figur 1. I hvilken grad mener du politiutdanningen tilfredsstiller samfunnets krav til politiet?

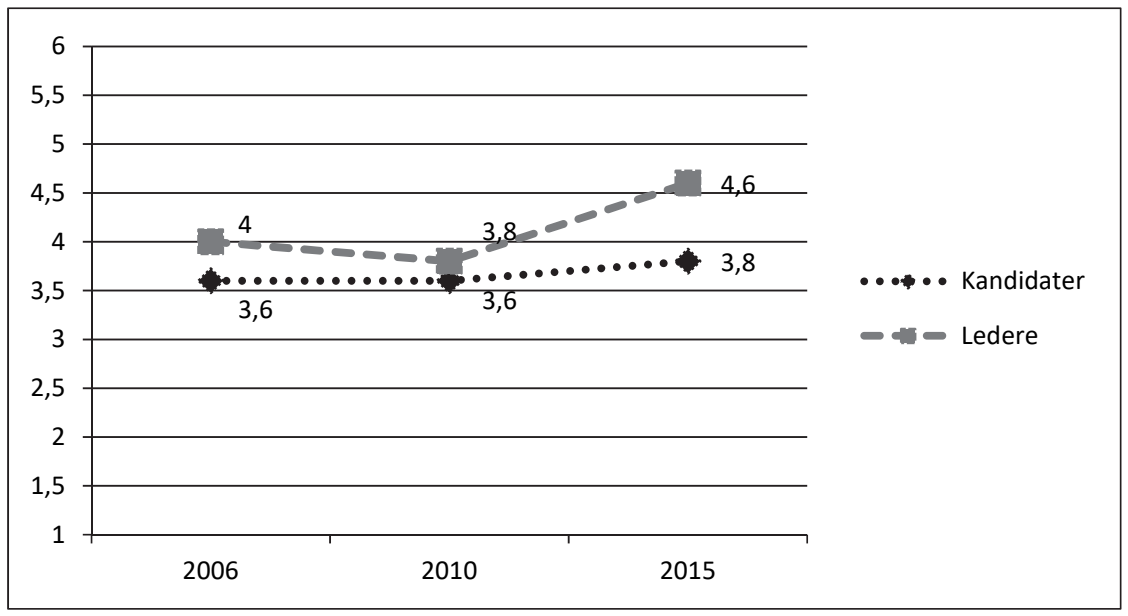

Figur 1 viser utviklingen i perioden 2006-2015. Denne viser at både kandidatene og lederne i gjennomsnitt plasserer seg over midtpunktet på skalaen i hele perioden. Ser man bak gjennomsnittstallene for 2015 finner man at nesten to tredjedeler av kandidatene plasserer seg på øvre del av skalaen (4-6) i sin vurdering av politiutdanningen. Det er relativt lite spredning hvor de aller fleste plasserer seg ganske nært gjennomsnittet på skalaen $(\mathrm{SD}=0,92)$. For ledernes del er tallet enda mer positivt, sett med Politihøgskolens øyne, hvor over 90 prosent krysser av på verdiene 4-6. Her er spredningen rundt gjennomsnittet enda mindre $(\mathrm{SD}=0,78)$. Forskjellen mellom kandidater og ledere i 2015 er også statistisk signifikant $(\mathrm{p}<0,01)$.

Utviklingen fra 2006 til 2015 viser ellers ganske liten endring i oppfatning blant kandidatene, mens endringen synes langt tydeligere for ledernes del. I 2015 mente lederne i langt større grad at utdanningen tilfredsstiller samfunnets krav til politiet enn tidligere. Denne endringen er også statisk signifikant $(p<0,01)$ når vi sammenlikner med 2006. (Dessverre har vi ikke tilgang på data fra 2010, men med tanke på at gjennomsnittet var 0,8 lavere enn 2015 og 0,2 lavere enn i 2006, så kan vi trygt anta at forskjellen fra 2010 også er statistisk signifikant). Vi kunne kanskje forventet det motsatte etter den massive kritikken politiet fikk etter 22 . juli tragedien i 2011, hvor politiets manglende operative kompetanse har blitt belyst i en rekke sammenhenger. 
En mulig forklaring på økte gjennomsnittstall for lederne på dette sentrale spørsmålet kan være at politiutdanningen i ledernes øyne har funnet en bedre balanse mellom teori og praksis etter omlegging til ny rammeplan i 2007 (Politihøgskolen 2007). Som tidligere nevnt innebar denne rammeplanrevideringen en langt tydeligere integrasjon av teori i praktiske politioppgaver med omleggingen fra fagsøyler til profesjonssøyler som organiseringsprinsipp for all faglig aktivitet i politiutdanningen (Aas 2019, s. 30). Videre kan det også tenkes at høgskoleutdanning for politistudenter i økende grad har oppnådd anerkjennelse i politietaten. Særlig med tanke på at Politihøgskolen har en relativt kortvarig historie.

\section{Hvor godt forberedt på politiyrket?}

Et annet overordnet spørsmål som er inkludert i 2015-undersøkelsen er følgende: «Hvor godt synes du utdanningen totalt sett har forberedt deg for arbeidsoppgavene du har møtt i politiet?». ${ }^{4}$ Tilsvarende ble lederne spurt «Hvor godt synes du utdanningen totalt sett har forberedt nyutdannede for arbeidsoppgavene de møter i politiyrket?». Også her skulle svaret plasseres på en skala fra 1-6. I figur 2 er gjennomsnittsverdien på skalaen for de to gruppene av respondenter oppgitt slik.

4. I kvalitetsundersøkelsene fra 2006 og 2010 ble det ikke stilt noe generelt spørsmål om hvor godt utdanningen har forberedt kandidatene til politiyrket, men om forberedelser til ulike deler av polititjenesten som oppgaver, ferdigheter og kunnskaper henholdsvis av politifaglig karakter, innen politi og juridiske områder - og innen kommunikasjon, samarbeid, etikk og samfunnsforståelse. 
Figur 2. Hvor godt har utdanningen totalt sett forberedt kandidatene for arbeidsoppgavene de har i politiyrket?

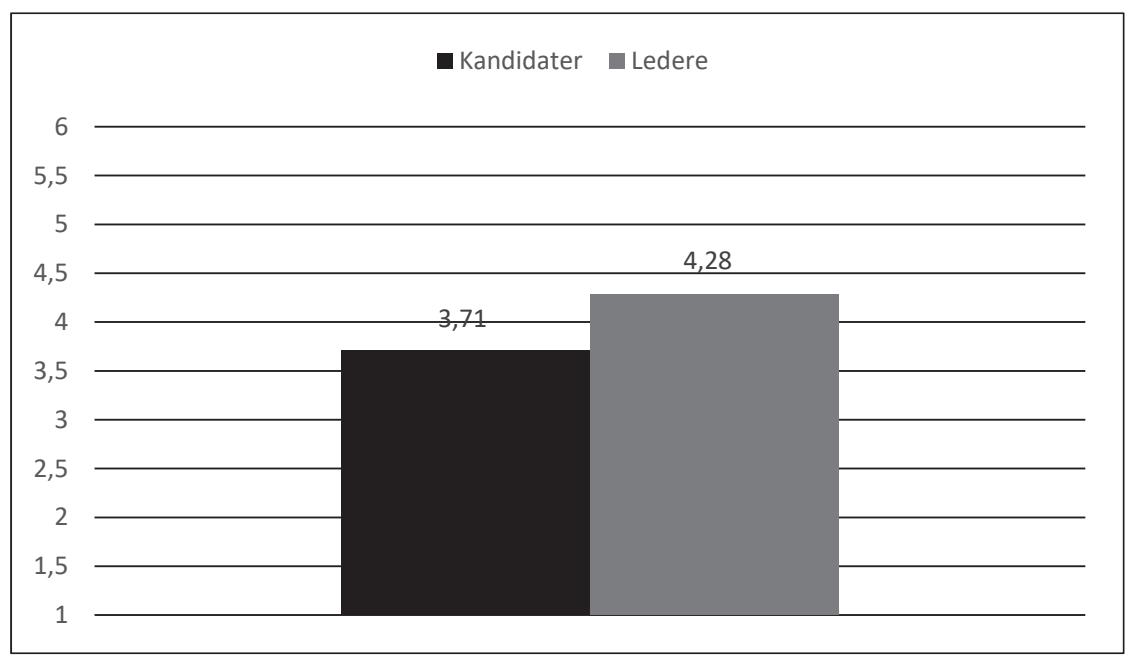

Igjen finner vi en tydelig forskjell mellom kandidater og ledere, der lederne vurderer utdanningens evne til å forberede kandidatene til yrket signifikant mer positivt enn kandidatene selv $(\mathrm{p}<0,01)$. Går vi bak gjennomsnittsverdiene som på forrige spørsmål, finner vi at over 80 prosent av lederne plasserer seg på den øvre delen av skalaen når de vurderer hvor godt kandidatene er forberedt totalt sett. Igjen finner vi en sterk konsentrasjon rundt gjennomsnittet $(\mathrm{SD}=0,85)$. Dette indikerer at lederne er godt fornøyd med kandidatenes kompetanse generelt sett.

Det synes derimot å råde større grad av tvil og forbehold blant kandidatene når de skal vurdere utdanningen i møtet med yrkesfeltet, selv om et flertall også her plasserer seg på den øvre del av skalaen og konsentrerer seg rundt gjennomsnittet $(\mathrm{SD}=0,96)$. Det er likevel ca. en tredjedel som plasserer seg på nedre del av skalaen (i hovedsak 3). Dette kan tolkes som at relativt mange nyutdannede har en forventning om at de skal være «ferdigutdannet» når de avslutter etter tre år på Politihøgskolen. Dette er en forestilling som finnes både i politietaten og blant studentene selv. De nyutdannedes forventning er ikke grunnløs. Nyutdannede må som regel mestre politioppgaver fra første dag på jobb uten noen formalisert veilederordning (Aas 2014, Sund m.fl. 2017). Likevel må det stilles spørsmål om politiutdanningen bør, og i det hele tatt kan, være slik at studentene kan gli nærmest sømløst over i yrkeslivet. Dette vil vi komme nærmere tilbake til i diskusjonen av funnene. 


\section{Rangering av kompetanseområder \\ Kandidatene}

Tidligere studier har vist at nyutdannede polititjenestepersoner vurderer både praktisk og relasjonell kompetanse som viktigere i deres yrkesutøvelse enn teoretisk kompetanse ${ }^{5}$ (Hove, 2010). Dette betyr ikke nødvendigvis at teoretisk kompetanse anses som uviktig, bare noe mindre viktig enn de andre kompetanseformene. På spørsmål om i hvilken grad kandidatene gjennom utdanningen har blitt kvalifisert for ulike sider av politiyrket, er det tydelig at det er den operative kompetansen de er mest usikker på. I figur 3 er kandidatenes vurdering av kvalifikasjoner på ulike kompetanseområder oppgitt. Når kandidatene også i denne undersøkelsen vurderer sine kvalifikasjoner innen de fleste kompetanseområdene av mer praktisk karakter som dårligst, kan det handle om at dette er de kompetanseområdene de anser som viktigst, og at forventningene til utdanningen derav ikke er innfridd. Dette kan begrunnes i nokså entydige funn fra politiforskningen om kunnskapsidealer i politiyrket, noe vi kommer tilbake til i diskusjonsdelen. Kandidatene vurderer sine egne kvalifikasjoner på denne måten:

5. «Praktisk kompetanse» i denne sammenhengen refererer seg til kompetanseområder som «praktiske ferdigheter, evne til å jobbe selvstendig og under press». «Relasjonell kompetanse» handler om «muntlig kommunikasjonsevne, toleranse og innlevelse», mens den «teoretiske kompetansen» er konstruert ut av kompetanseområder som «bred og generell kunnskap, yrkesspesifikk kunnskap, kunnskap om planlegging og organisering, innsikt i regler og bestemmelser» (Hove 2012, s. 82). 


\section{Figur 3. Kandidatenes rangeringer av egne kvalifikasjoner} på de ulike kompetanseområdene

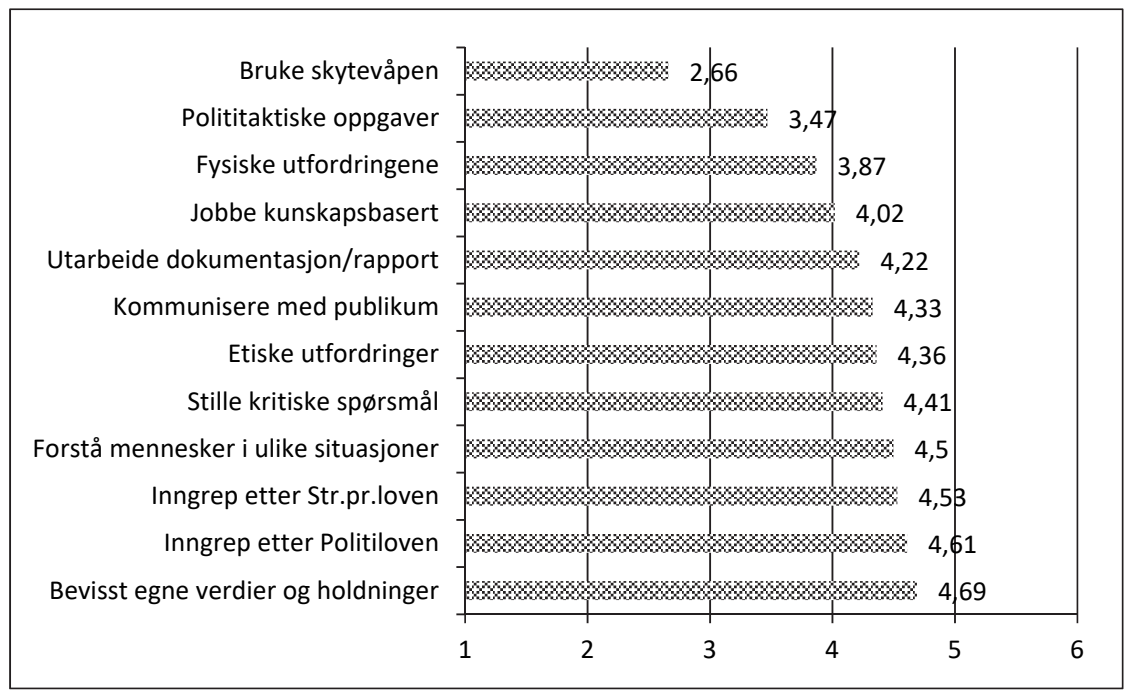

Kandidatene rangerer sine kvalifikasjoner knyttet til bruk av skytevåpen lavest av de ulike politifaglige kompetanseområdene de ble forelagt i denne undersøkelsen. Det er også det eneste kompetanseområdet som ligger på «den negative siden» av skalaen $\mathrm{i}$ den forstand at et flertall plasserer seg på den nedre delen av skalaen (13). Trolig vektlegges våpenkompetanse sterkt til tross for at sannsynligheten for at kandidatene noen gang kommer i en situasjon der de må anvende skytevåpen er svært liten (Knutsson og Strype 2002). Samtidig er mulighetene for våpenbruk alltid til stede, og noen polititjenestepersoner vil før eller siden komme i en slik situasjon der våpenet må tas i bruk i en skarp situasjon. Med tanke på de potensielt fatale konsekvensene det kan få både for innbyggere og for egen sikkerhet hvis man ikke er tilstrekkelig beredt, er det forståelig at våpenkompetanse vektlegges.

Det lave tallet på «bruk av skytevåpen», kan også forstås som et resultat av at våpenbruk har blitt en økt realitet for politiet de siste årene. Både den pågående bevæpningsdebatten og den midlertidige generelle bevæpning av politiet er eksempler på det. Denne studien er gjennomført i løpet av en periode da norsk politi 
var midlertidig generelt bevæpnet. ${ }^{6}$ Dette medførte en økt oppmerksomhet på politiets skyteferdigheter. Det fokuset kan også ha bidratt til økt usikkerhet om egen kompetanse når det gjelder bruk av skytevåpen. Samfunnsdebatten om politirollen har i økende grad rettet seg mot politiets evne til å løse beredskapsoppgaver.

En rekke offentlige publikasjoner i kjølvannet av terrortragedien i Norge 22. juli 2011 har understreket betydningen av denne type operativ beredskap (se NOU 2012; 14, NOU 2013; 9, og NOU 2017; 9). Det er grunn til å tro at generell bevæpning er mer fremme $\mathrm{i}$ bevisstheten hos den enkelte polititjenesteperson nå enn bare for få år siden. At egen kompetanse til anvendelse av skytevåpen er rangert så lavt, kan også forstås som ydmykhet og respekt overfor et så kraftig og alvorlig maktmiddel.

Figur 3 viser videre at «Polititaktiske oppgaver» og «Fysiske utfordringer» er noe de nyutdannede er relativt usikre på sammenliknet med andre kvalifikasjoner. Derimot synes de å være relativt trygge når det gjelder kvalifikasjoner som «Inngrep etter Straffeprosesslov og Politiloven». Slik sett er det primært de praktiske operative ferdighetene de er usikker på, mens de føler seg relativt sikker i de praktiske juridiske ferdighetene.

Spørsmålet om «våpenkompetanse» var ikke med i de foregående kvalitetsundersøkelsene. Spørsmålene tilknyttet kompetanseområder har endret seg noe mellom 2006/2010-undersøkelsen og denne undersøkelsen fra 2015, og vi kan ikke sammenligne disse tre kvalitetsundersøkelsene på alle punkter. Likevel er flere spørsmålsstillinger videreført i den siste undersøkelsen. Det er seks kompetanseområder i kvalitetsundersøkelsene som kan sammenlignes direkte over tid. I figur 4 er gjennomsnittsskår for henholdsvis 2006 og 2015 oppgitt på disse seks kompetanseområdene. Statistiske signifikante forskjeller er angitt med asterisk $(*)$.

6. Den 25. november 2014 ble politiet i Norge bevæpnet i ca. fire uker. Bevæpningen ble fornyet åtte ganger. Det innebar at politiet bar våpen i ordinære tjeneste kontinuerlig i en periode på over 14 måneder, frem til 3. februar 2016. Årsaken bak bevæpningen var Politiets sikkerhetstjenestes (PST) vurdering om at politiet kunne være et terrormål (NOU 2017: 9, s.130). 
Figur 4. Vurdering av kvalifikasjoner 2006 og 20157. Kandidater.

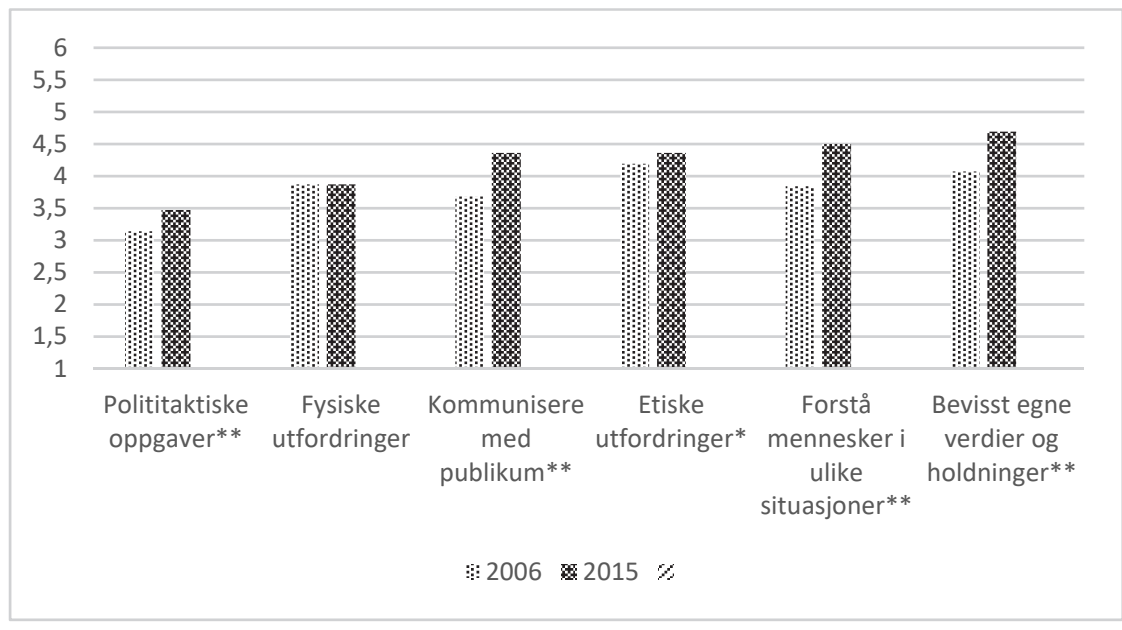

$* \mathrm{p}<0,05, * * \mathrm{p}<0,01$

For de «polititaktiske oppgaver», som handler om operative tilnærminger i mer tilspissede hendelser, har tallet steget blant kandidatene fra undersøkelsene i 2006. Det samme gjelder spørsmålene om «å kunne forstå mennesker i ulike situasjoner», «kommunisere med publikum», «være bevisst egne verdier og holdninger» og «etiske utfordringer». Vurderinger av egne kvalifikasjoner for «fysiske utfordringer» viser omtrent samme nivå på gjennomsnittstallene. Jevnt over viser tallene at nyutdannede ser ut til å vurdere sine egne kvalifikasjoner som bedre enn de som deltok i undersøkelsene i 2006 på en rekke kompetanseområder for politiutøvelse.

\section{Lederne}

I figur 5 er politiledernes vurderinger av de nyutdannedes kvalifikasjoner på de samme kompetanseområdene oppgitt slik:

7. Dessverre har vi ikke tilgang på data fra 2010 på disse kvalifikasjonene. 
Figur 5. Ledernes rangeringer av kandidatenes kvalifikasjoner på de ulike kompetanseområdene

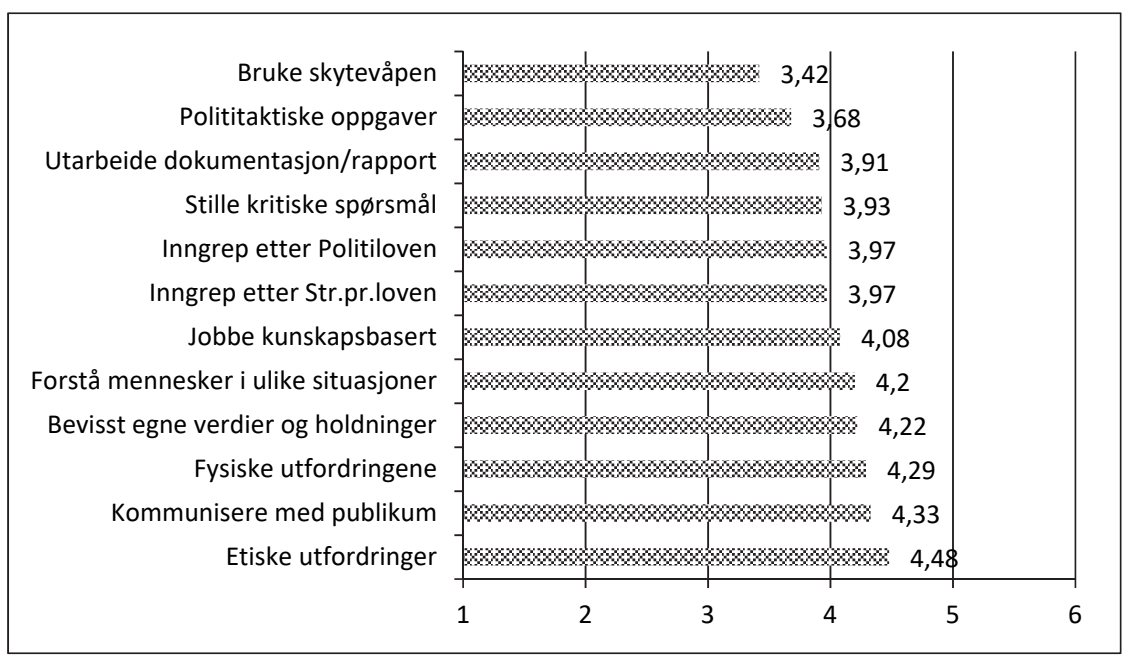

Som figuren viser rangerer lederne i likhet med kandidatene kompetanse på «bruk av skytevåpen» lavest, men dog høyere enn kandidatene selv. Det samme gjelder «polititaktiske oppgaver» og, ikke minst, «fysiske utfordringer». Derimot synes politilederne å være noe mer usikre når det gjelder kandidatenes juridiske kompetanse, i alle fall sammenliknet med kandidatenes egenoppfatning. Ellers synes både kandidatene og lederne å rangere de relasjonelle kompetansene slik som kommunikasjon med publikum m.m. ganske høyt og høyere enn de mer fysiske og håndfaste kompetanseområdene. I figur 6 har vi sammenlignet gjennomsnittsskår over tid blant lederne og signifikanstestet forskjellene. 
Figur 6. Vurdering av kvalifikasjoner 2006 og $2015{ }^{8}$ Ledere

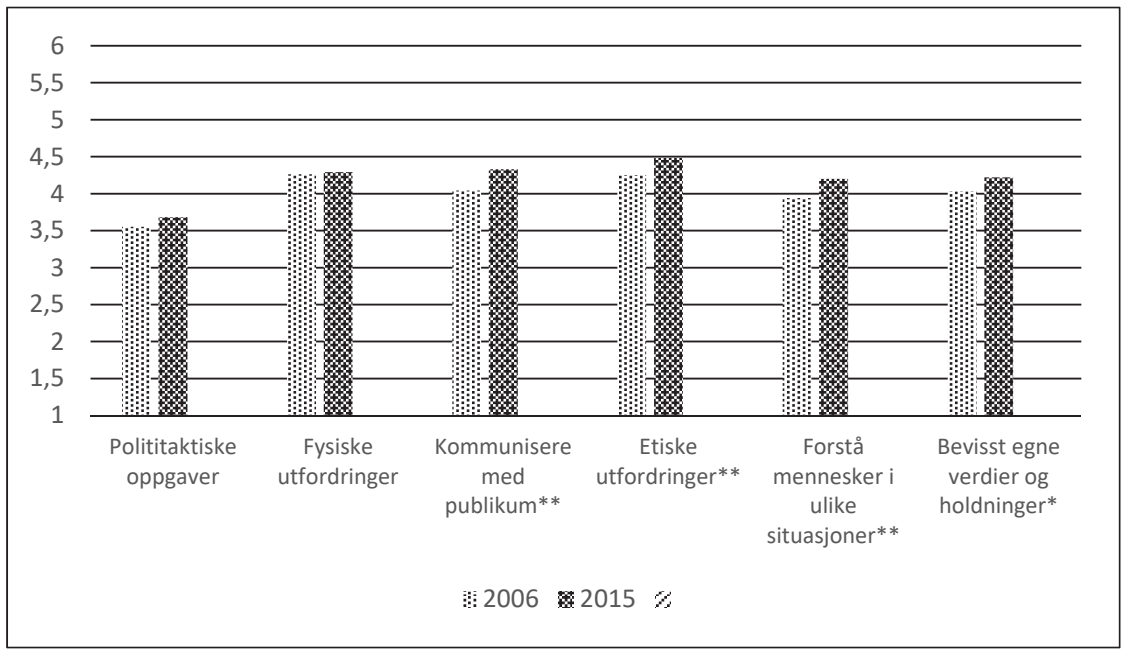

${ }^{*} \mathrm{p}<0,05,{ }^{* *} \mathrm{p}<0,01$

Av figuren ser vi at lederne også har styrket sin oppfatning av de nyutdannedes kompetanse på flere av områdene som kan sammenlignes over tid. Unntakene er «Polititaktiske oppgaver» og «Fysiske utfordringer» som er uforandret (ikke statistisk signifikant). Det samsvarer for øvrig godt med ett av hovedfunnene i figur 1 som dokumenterer at lederne i økende grad finner at politiutdanningen tilfredsstiller samfunnets krav til politiet.

Avslutningsvis har vi i figur 7 sammenstilt kandidatenes og ledernes gjennomsnittsskår på ulike kompetanseområder i 2015 og signifikanstestet forskjellene.

8. Dessverre har vi ikke tilgang på data fra 2010 på disse kvalifikasjonene. 
Figur 7. En sammenligning av kandidater og ledere mht. Vurdering av kvalifikasjoner

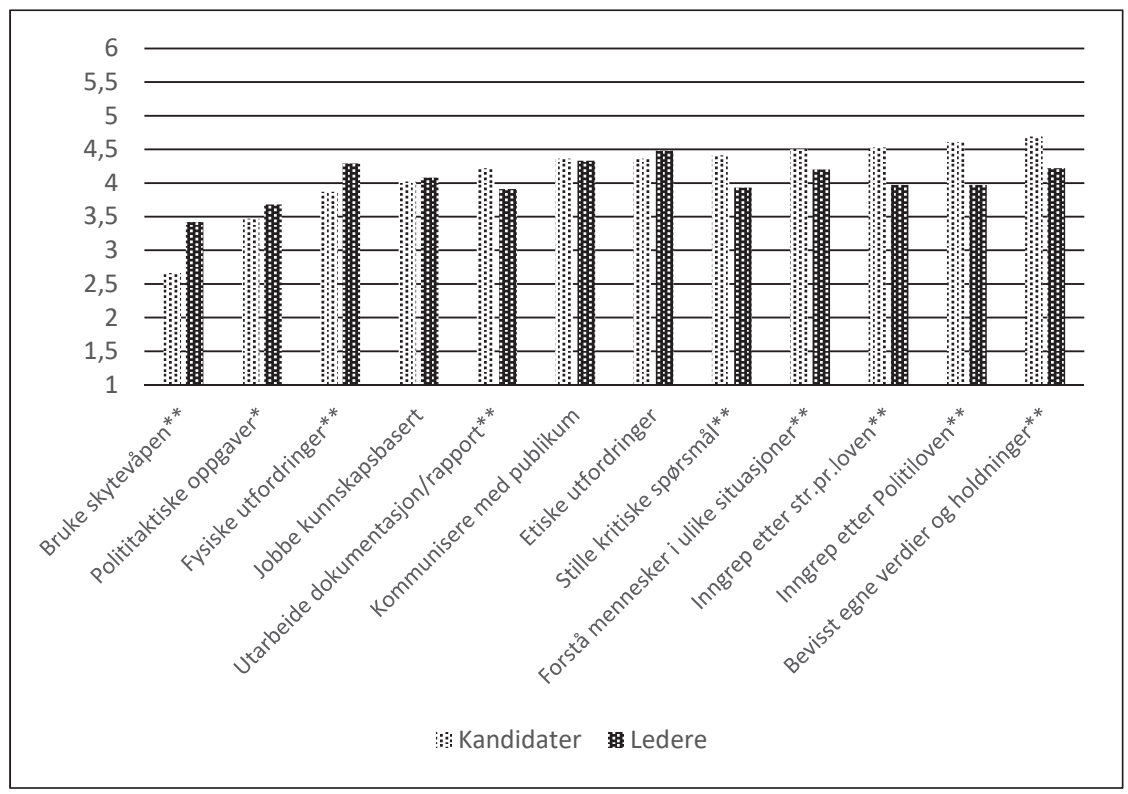

$* \mathrm{p}<0,05, * * \mathrm{p}<0,01$

Forskjellene mellom kandidatenes egenvurdering og ledernes vurdering av kandidatenes kvalifikasjoner viser et interessant mønster i figuren over. Lederne gir en mer positiv vurdering av kandidatenes fysisk orienterte kompetanse enn det kandidatene selv gjør (bruk av skytevåpen, polititaktiske oppgaver og fysiske utfordringer). Kandidatene er derimot mer positive enn lederne til sine mer kognitivt orienterte kompetanseområder som i større grad tilegnes gjennom studier (stille kritiske spørsmål, forståelse av seg selv og andre og inngrep etter loven).

\section{Diskusjon}

\section{Kunnskapsidealene i politiet}

Datamaterialet for denne undersøkelsen forteller at politilederne vurderer politiutdanning som godt tilpasset samfunnets krav til politiet. Dette understøttes av tallene som reflekterer deres syn på utdanningen som forberedelser til politiyrkets oppgaver. Disse tallene har forsterket seg i de senere årene. Det gjelder også for 
de nyutdannede til tross for at de ikke har like tydelig oppfatning av politiutdanningens relevans. Når kvalitetsundersøkelsen ber om svar på de ulike ferdighetsog kompetanseområdene i politiyrket spriker imidlertid tallene. Både de nyutdannede og deres ledere vurderer kvalifisering for bruk av skytevåpen og polititaktiske oppgaver som svakest. Vi har lansert flere mulige forklaringer i den forbindelse, både i muligheten for at politiutdanningen er svak på dette området og at forventningene til denne type ferdighet er særlig sterke i politikulturen. Operative ferdigheter, særlig i de mer pressede og tidskritiske situasjoner, har en spesiell status i denne yrkeskulturen (Aas 2014 a,b). Disse ferdighetene har til tider nærmest fått mytiske dimensjoner. Reiner har spissformulert denne myten om politimannen som en slags «racing-driver or boxer in a blue uniform» (Reiner 2000, s. 89). Politiforskningen kan imidlertid fremvise det rutinepregete, kjedelige og trivielle i politibetjentenes hverdag, der venting på at noe skal skje dominerer tjenesten (se for eksempel Bayley 2005, Finstad 2000).

Når grunnlaget for denne studien er politiutøveres egne vurderinger av politiutdanningen i forhold til hvilken kompetanse de nyutdannede er i besittelse av, er det grunn til å utfordre de hegemoniske kunnskapsidealene i politietaten. Spørsmålet kan forankres i hva sentrale nordiske politiforskere har identifisert som «riktigt polisarbete» (Granér 2004, s. 115) eller «det egentlige politiarbeidet» (Finstad 2000, s. 95). Finstad utdyper det på denne måten i sine studier av norsk politi; «Det egentlige politiarbeidet er noe som er renere, som tydeligere viser hvem som er skyldig og uskyldig (...)» (Finstad 2000, s. 97). Dette er et funn også i dansk politiforskning, der heller ikke danske politiutøvere oppfatter uklare konflikter og sammensatte moralske spørsmål som «skikkelig» politiarbeid (Holmberg 1999).

Setter vi disse funnene i en større tolkningsramme, vil vi for eksempel finne Gundhus som dokumenterer at det er gatekunnskap som verdsettes høyest i politikulturen - ikke analytisk, generell, akademisk og vitenskapelig kunnskap. I Granérs forskning presenteres svenske politiutøvere som setter det handlingsorienterte i sentrum, der konkrete og selvopplevde hendelser har høyest verdi (Granér 2004). I Olsen og Sjøtrøs dybdeintervjuer av norske innsatsledere identifiseres taus kunnskap i kontrast til formalisert og eksplisitt kunnskap. Taus kunnskap er i sin rendyrkede form subjektiv, personlig, kontekstavhengig og vanskelig å dele. Eksplisitt kunnskap beskrives derimot som objektiv, upersonlig, kontekstuavhengig og enkel å dele (Olsen og Sjøtrø 2013, s. 25). Taus kunnskap handler i stor grad om erfaringsbasert kunnskap, mens den eksplisitte kunnskapstypen har sin åpenbare referanse til formalisert og etterprøvbar skolekunnskap. Ikke overraskende er det den tause kunnskapstypen som synes å ligge til grunn for innsatsle- 
dernes virke. Når oppdragene preges av press, risiko og stress forteller innsatslederne at det er magefølelsen, teft, intuisjon og improvisasjon som leder dem til beslutningene. Verdier som bare i begrenset grad kan tilegnes i en utdanningsfase, nettopp fordi de i så stor grad er erfaringsbaserte.

En vesentlig innvending til denne politiforskningen er at den i stor grad er forankret til det operative politiarbeidet og mindre til de andre polisiære hoveddispliner som etterforskning og forebyggende politiarbeid. Det er grunn til å tro at kunnskapsidealene og verdimønstrene er noe ulike mellom disse disiplinene fordi arbeidet på en etterforskningsavdeling fortoner seg svært annerledes enn det uniformerte og operative politipatruljearbeidet. Etterforskningsarbeid krever ofte fordypning i både dokumenter og langvarige avhør, patruljetjeneste er derimot langt mer handlingsorientert mot oppdukkende her-og-nå-oppgaver som ofte krever hurtige løsninger.

Når lederne mener at de nyutdannede er bedre forberedt til politiyrket enn hva de nyutdannede selv opplever, kan det følge flere mulige forklaringer. Mest nærliggende forklaring ligger $i$ at lederne oftere har lavere og mer realistiske forventninger til kandidatene. De vet av erfaring at det tar tid å tilpasse seg dette yrket, og at utdanning er noe annet enn selve yrket som utdanningen skal forberede for. Kandidatene derimot vil trolig i større grad møte et praksisfelt både med usikkerhet og utålmodighet, kanskje også med en følt forventning om at de bør være i stand til å løse yrkeskontekstens mangfoldige utfordringer. Vi ser heller ikke bort fra at lederne ser at kandidatene er besittelse av en kompetanse som de kanskje selv aldri ble eksponert for i sin egen politiutdanning. Politiutdanningen har som tidligere beskrevet utviklet seg fra etats- til høgskole - og utviklet seg videre til en langt mer profesjonsnær utdanning i høgskolens relativt kortvarige historie.

\section{Hva skal en bachelorutdanning for politiet vere?}

I en evaluering av norsk politiutdanning, foretatt av Universitetet i Umeå, settes det kritiske merknader til praksisdelen av politiutdanningen på denne måten: ${ }^{9}$ «Varför kommer praktiken så tidigt i studenternas utbildning? Varför omfattar den ett helt år?» (Lauritz, Bergh og Karp 2016, s. 15). Denne analysen påpeker at den erfaringsbaserte kunnskapen blir for dominerende, med den konsekvens at det;

9. Den norske politiutdanningen leder frem til en treårig bachelorgrad, og er organisert gjennom studieårene B1, B2 og B3. Mellomåret (B2) gjennomføres i politipraksis på ulike politienheter i landet. 
«ges förutsättningar för en stark reproduktion av praxisrelaterade kunskaper, normer och värderingar. Därigenom kan ett reflekterande, kritiskt och utvecklingsinriktat förhållningssätt till polisyrket riskeras» (Lauritz, Pontus Bergh og Karp 2016, s. 15).

Det til tross for Politihøgskolens uttalte intensjoner om en kunnskapsbasert utdanning som svarer til profesjonelle og vitenskapelige forventninger (Politihøgskolen 2013b, 2014). Et utfordrende spørsmål for Politihøgskolen er som tidligere nevnt hvorvidt den gjør sine studenter mest mulig klar for praktisk politiarbeid fra dag 1 (etter press fra røstene i politietaten som etterspør mest mulig «ferdigvare» uteksaminert fra høgskolen). Skal utdanningen heller ta sikte på å utstyre studentene med en kunnskapsplattform som kan vokse og gro gjennom et langt politiliv? I den førstnevnte tenkningen vil en innrette utdanningen i en langt mer praktisk retning enn om en har et bredere og videre siktemål.

Det er neppe noen tvil om at tilegnelsen av analytiske ferdigheter og evnen til å lære videre har en lengre holdbarhet enn praktiske ferdigheter som stadig må endres i tråd med nye krav og bedre standarder for konkret oppgaveløsning. På den annen side bør ikke praktiske oppgaver skilles så skarpt fra teori og analyse. Politiutdanningen har som hovedmål å integrere disse dimensjonene, og analytisk- og teoretisk kompetanse vil kunne komme til nytte i de praktiske oppgavene allerede i startfasen av yrkeskarrieren.

Den kritiske innvendingen til kvalitetsundersøkelsen blir dermed dens validitet. Hvor relevant er undersøkelsen for å måle kvaliteten på de nyutdannede? I tråd med målsetningene for utdanningen som nettopp er skissert er det i stor grad avgrensede og identifiserbare kunnskaper og ferdigheter som gjøres til gjenstand for måling - og ikke i samme grad evnen til egenutvikling og videre læring i dette yrket. Her ligger det et tydelig forbedringspotensial i fremtidige kvalitetsundersøkelser.

\section{Konklusjon}

Artikkelens overordnede spørsmål om hvorvidt politiutdanningen fortsatt holder mål, er basert på data fra tidligere kvalitetsundersøkelser i sammenligning med de ferskeste funnene som er presentert i denne studien. Dette overordnede spørsmålet ble konkretisert til å handle om i hvilken grad nyutdannede politibetjenter og deres ledere vurderer politiutdanningen som en tilstrekkelig forberedelse til politiyrket.

På grunnspørsmålet om politiutdanningen tilfredsstiller samfunnets krav til politiet viser tallene økning siden målingene i 2006 og 2010. Det gjelder svarene fra både de nyutdannede og deres ledere. Videre viser det seg at de nyutdannede 
vurderer sine egne kvalifikasjoner som bedre enn hva nyutdannede gjorde både $\mathrm{i}$ 2006 og 2010 på flere av de definerte ferdighetsområdene for politiutøvelse. Lederne har et forbedret inntrykk av de nyutdannedes nivå på de fleste av områdene.

Kravet om handlingskompetanse tidlig i en politikarriere kan fort bli både urimelig og uheldig. Uheldig fordi et slikt krav vil kunne vri utdanningen $\mathrm{i}$ for stor grad mot praktisk ferdighetstrening på bekostning av andre vesentlige verdier i utdanningen, og urimelig fordi et erfaringsbasert yrke som politiyrket krever erfaring i gjentatte handlingsmønstre over tid. Det kan vanskelig tilegnes i en utdanningskontekst.

Når kvalitetsundersøkelsen ber de nyutdannede svare på spørsmål om utdanningens tilpasning til politiyrket, kan det reises spørsmål om hva Politihøgskolen skal bruke disse svarene til. Når de nyutdannede gang på gang påpeker utdanningens begrensede relevans for politiyrket, er det likevel lite trolig at Politihøgskolen vil endre vesentlig i sine fagplaner. Nettopp fordi høgskolen har et langt bredere og lengre siktemål enn de nyutdannede.

Kvalitetsundersøkelsene har åpenbare begrensninger. Først og fremst i det faktum at det bare er politiutøvere som vurderer egen kompetanse i forhold til utdanningsbakgrunn. En annen svakhet er vektleggingen av identifiserbar «her-ognå-kunnskap» i politiutøvelsen som de nyutdannede utfører, og i mindre grad kunnskapssekken som skal vokse og gro i de nyutdannedes fremtidige politikarriere. Sistnevnte verdi er også et viktig mål for politiutdanningen.

\section{Litteratur}

Abbott, A. (1998). The Systems of Professions: An Essay on the Division of Expert Labor.

Abbott, A. (1998). The Systems of Professions: An Essay on the Division of Expert Labor. University of Chicago Press.

Bayley, David H (2005): What do the police do? I: Newburn, Tim (ed.) Policing Key Readings. Devon. Willian Publishing.

Bråten, O.A. (upublisert). Kvalitetsundersøkelsen 2010. Oslo: Politihøgskolen

Finstad, L. (2000). Politiblikket. Oslo. Pax Forlag A/S.

Granér, R. (2004). Patrullerande polisers yrkeskultur. Lund. Socialhögskolan, Lunds Universitet.

Gundhus, H.I. (2009). For sikkerhets skyld. IKT, yrkeskulturer og kunnskapsarbeid i politiet. Unipub.

Hansen, H. (upublisert). Utdrag fra kvalitetsundersøkelsen 2006. Oslo: Politihøgskolen

Heggen, K. (2010). Kvalifisering for profesjonsutøving. Sjukepleiar - lærar - sosialarbeidar. Oslo: Abstrakt forlag.

Holmberg, L. (1999). Politiets skøn i retssociologisk belysning. København. Det juridiske Fakultet ved Københavns Universitet. 
Hove, K. (2010). Avsluttende studentevaluering i Bachelorutdanningen: Avgangsstudenters vurdering av undervisning og utdanning ved Politihøgskolen, Kull 05-08. Oslo: Politihøgskolen

Hove, K. (2012). Politiutdanning i Norge - fra konstabelkurs til bachelorutdanning [Police Education in Norway]. Oslo. Politihøgskolen.

Justis- og beredskapsdepartementet (2015). Endring av våpeninstruks for politiet. Hentet fra https://www.regjeringen.no/no/aktuelt/endring-av-vapeninstruks-for-politiet/id2395995/

Lauritz, L.E., Bergh, P. \& Karp, S. (2016). Norsk polisutbildning 2016. En gransking av hogskoleutbildning (Evaluering skrevet for Politihøgskolen). Upublisert.

Messel, J. og Smeby, J-C (2017) Akademisering av høyskoleutdanningene? I Mausethagen, S. og Smeby, J-C (red). Kvalifisering til profesjonell yrkesutøvelse. Universitetsforlaget. Oslo

Molander, A og Terum, L.I. (2010). Profesjonsstudier - en introduksjon. I; Molander, A og Terum, L.I.; Profesjonsstudier (red.). Universitetsforlaget. Oslo.

NOU (2012; 14). Rapport fra 22. juli-kommisjonen. Oslo: Departementets sikkerhets- og serviceorganisasjon.

NOU $(2013$; 9). Ett politi - rustet til å møte fremtidens utfordringer. Oslo; Departementets sikkerhets- og serviceorganisasjon.

NOU (2017; 9). Politi og bevæpning - legalitet, nødvendighet, forholdsmessighet og ansvarlighet. Oslo: Departementets sikkerhets- og serviceorganisasjon.

Nygren, P. og Fauske, H (2010) Handlekompetence og ideologi. Individ, profession og samfunn. Dansk psykologisk forlag

Olsen, P.I. og Sjøtrø, A. (2013). Magefølelse som kunnskapsform. En innsatsleders tilnærming til krevende oppdrag. Masteravhandling. Handelshøjskolen i København og Institut for Uddannelse og Pædagogik, Aarhus.

Politidirektoratet (2016). Strategiplan for politiets trafikktjeneste 2016-2019. Hentet fra http://docplayer.me/20304978-Strategiplan-for-polititjeneste-pa-veg.html

Politihøgskolen. (u.å.). Strategi 2017-2021. Oslo: Politihøgskolen.

Politihøgskolen (2007). Rammeplan for Bachelor-politiutdanning. Godkjent av Justis- og politidepartementet 10. juli 2007.

Politihøgskolen (2013a). Opptaksrapport 2013. Ikke publisert.

Politihøgskolen (2014). Rammeplan for Bachelor-politiutdanning. Godkjent av Justis- og beredskapsdepartementet 23. januar 2014.

Politihøgskolen (2018). Kvalitetsutvikling. Årsrapport 2017-2018. Bacheloravdelingen - Oslo.

Reiner, R. (2000). The Politics of the Police. Third Edition. Oxford University press.

Smeby, J.-C. og Mausethagen, S (2017) Profesjonskvalifisering. I Mausethagen, S. og Smeby, J$\mathrm{C}$ (red). Kvalifisering til profesjonell yrkesutøvelse. Universitetsforlaget. Oslo

Stortingsmelding 16 (2016-2017) Kultur for kvalitet i høyere utdanning. Det kongelige kunnskapsdepartement.

Sund, A., Aas, G., Nilsen M., Thomassen G. og K. Hove (2017). Kvalitetsundersøkelsen 2015

Strype og Knutsson (2002). Politiets bruk av skytevåpen. PHS Forskning 2002: 1.

Ulvskov Nielsen, A. (2016). Vurdering af ny norsk fagplan for bachelor-politiuddannelsen. Internotat. Upublisert.

Universitet- og høyskoleloven (2005). Lov om universitet og høyskoler. Hentet fra https://lovdata.no/dokument/NL/lov/2005-04-01-15 
Aas, G. (2014a). Politiutøveres syn på politiutdanningen: Kvalitetsundersøkelsen 2014. PHS Forskning 2014.

Aas, G. (2014b). Politipraktikere og deres syn på politiutdanningen. Nordisk Politiforskning vol. 1, Nr.2/2014. 124-148.

Aas, G. (2019). »Kampen om norsk politiutdanning«. I Tidsskrift for Professionsstudier. Nr. 28, 2019. s. 26-34. 